\title{
Use of Native Microorganisms as an Alternative for Biological Removal of Organic Matter in Wastewater from the Pharmaceutical Industry
}

\author{
Paola Bautista Duarte1, Laura Pramparo ${ }^{1 *}$ \\ ${ }^{1}$ Faculty of Engineering, Nueva Granada Military University, 110111 Bogotá, Carrera 11 no. 101-80, Colombia \\ * Corresponding author, e-mail: laura.pramparo@unimilitar.edu.co
}

Received: 18 March 2021, Accepted: 01 July 2021, Published online: 08 November 2021

\begin{abstract}
The impact of non-domestic wastewater (nDWW) on water bodies every day is increased, considering the different pollutants that are entering and these are not regulated, also that the effects of these are not known in the ecosystems. In the case of the pharmaceutical industry, the various products they generate can contribute from non-steroidal anti-inflammatory analgesics (NSAIDs), antihypertensives, hormones, antibiotics, among others; they are being detected in surface waters and it is necessary to create strategies to improve treatment systems and thus reduce their effects on water systems. In this work, the native microorganisms from nDWW of the pharmaceutical industry were used to evaluate their ability to influence the removal of organic matter, working in mixed culture, where it was evidenced that in a 24 hours they could remove $45.82 \%$ of the organic matter measured by the chemical oxygen demand (COD) and at 48 hours $90.59 \%$ removal. The above shows that the use of microorganisms can contribute to the reduction of COD and pollutants in an effective, environmentally friendly and, more efficient way than conventional methods. Besides, the qualities of tolerance to four NSAIDs by 16 morphotypes are evidenced, and how they can be profiled in the future to be potentialized and reach the mineralization of these emerging pharmaceutical pollutants.
\end{abstract}

Keywords

bioprospecting, biological removal, COD, pharmaceutical industry

\section{Introduction}

Water is one of the most important compounds on the planet and its use for human and industrial consumption, preservation of flora and fauna, is given by the physical, chemical and biological characteristics, which can be modified by the entry of effluents or runoff [1]. Historically, the development of industry and urban centers occurs near bodies of water to supply the population's supply, resulting in the increase in municipal and industrial discharges to bodies of water generating an imbalance in physical parameters, chemical and biological affecting the characteristics of the recipient body $[2,3]$. The discharge of wastewater is considered as an important source of pollutants to the environment, especially due to the load of organic matter that cannot be removed and that, in it, different substances are combined that are not treated within the plants and are released into the environment without knowing their consequences [4]. To establish the impact of non-dDomestic wastewater (nDWW), it must begin with the determination of the physical, chemical and biological parameters. In this way, knowing what its characteristics are, it can be established what will be its effect on the water body that receives it and the type of pollutant that enters [5-7]. In general, nDWW contains contaminants such as fats and oils, heavy metals, organic matter, excrement, disinfectants, soaps, among others, which are regulated by existing legislation and determining their concentrations allows defining the type of treatment that must be carried out before being discharged into the environment [8].

Currently, there is worldwide concern about the presence in the surface, marine, and underground waters of substances such as surfactants, plasticizers, additives, surfactants, epoxy resins, pharmaceutical and personal care products (PPCP), and different chemical compounds, which have been named as emerging pollutants (EP). 
Known effects of some of these compounds include alteration of the endocrine system in animals, estrogenic and antiandrogenic effects in rats, complications in pregnancy, affecting gill and kidney tissue in freshwater fish, affecting the immune system of the seal, and resistance of bacterial pathogens to antibiotics $[9,10]$.

Wastewater treatment systems implement physical, chemical, or biological mechanisms, and are the quintessential alternative for the elimination of organic and inorganic compounds. However, the removal rates determined for pharmaceutical products vary widely, as removal efficiency depends on by the compound's physicochemical properties, reactor design, and operating conditions [11].

This fact means that through punctual and non-punctual discharges of domestic wastewater (DWW) and non-domestic wastewater (nDWW), within which are hospital effluents, runoff from agricultural and livestock activities, septic tanks, improper final disposal of pharmaceutical products, among others, are one of the main routes of entry of pharmaceutical products to different aquatic systems, including drinking water catchment points $[12,13]$.

It is considered that wastewater treatment systems should be improved to remove Emerging Pollutants. Some authors show that the use of aerobic, anaerobic, or anoxic biological treatments can influence the removal of substances such as ibuprofen, naproxen, among others, with effectiveness processes between 20 and $80 \%$, as well as, they remain efficient in removal organic matter, nutrients and solids above $80 \%[14,15]$.

Biological treatments attract attention as degradation processes where microorganisms such as bacteria, algae, and fungi are used that can mineralize high molecular weight molecules and lead them to simple compounds such as water or carbon dioxide, by using pollutants as a source of carbon or energy, inducing the production of enzymes for their assimilation, in addition to having the ability to tolerate the toxicity of different substances [16].

The microorganisms find the appropriate characteristics in terms of tolerance and consumption of pollutants, metabolic routes, and proteins. A bioprospecting process must be a systematic search like microorganisms by classical or modern laboratory techniques, such as the use of metagenomics, which make it possible to take advantage of the metabolic potential, as in this case, to remove pollutants and reduce the impact on ecosystems [17].

Biological degradation processes based on microorganisms have always been a viable alternative for the treatment of different pollutants [11]. However, the pharmaceutical industry presents variability of substrates taking into account the different production lines, which affects the removal of organic matter that may have values above the regulations. There is a lack of microbial isolates that can be used in bioaugmentation processes to increase degradation rates, together with the study of their enzymatic activities that allow improving the $\mathrm{nDWW}$ treatment systems and tolerate the changes that occur according to the process of manufacture.

Therefore, the objective of this work is to take advantage of the native microorganisms present in $\mathrm{nDWW}$ of the pharmaceutical industry as a biological alternative for the removal of organic matter and how to profile them as a mixed culture that in the future may influence the removal of Emerging Pollutants such as non-steroidal anti-inflammatory drugs (NSAIDs).

\section{Materials and methods 2.1 Microorganisms}

From the INV-ING-2373 project of the Nueva Granada Military University, the microbiological characterization of nDWW from the pharmaceutical industry was carried out. The sample was grown in Nutrient agar (Hi Media Laboratories, Pennsylvania, USA), Cetrimide agar (Hi Media Laboratories, Pennsylvania, USA), and Macconkey agar (Hi Media Laboratories, Pennsylvania, USA), all medium was sterilized at $121^{\circ} \mathrm{C}, 15$ pounds of pressure for 15 minutes (Autoclaves Industriales Sterilof, Colombia). A total of 328 bacterial strains were obtained, from these strains 64 were Pseudomonas, 59 were coliforms and 205 strains were not identified bacteria. Each isolate was purified, and this was evaluated hydrolytic enzyme presence (proteases, lipases, and amylases), and tolerance tests were carried out to pharmaceutical compounds. The individual selection processes began to form a future consortium that will use as an alternative to treat wastewater pharmaceuticals.

\subsubsection{Determination of strains with hydrolytic activity}

The 328 strains were reactivated by isolation on nutrient agar plates (Hi Media Laboratories, Pennsylvania, USA); each microorganism was grown in $30^{\circ} \mathrm{C}$ for 24 hours, and their morphology macro and microscopic corroborated. Subsequently, each of these was evaluated for its ability to grow in $1 \% \mathrm{w} / \mathrm{v}$ milk agar (proteolytic), Tween 20 agar (lipolytic) and $1 \%$ starch agar (amylolytic), for which each strain was grown in triplicate in the Agars mentioned and incubated at $35^{\circ} \mathrm{C} \pm 0.5^{\circ} \mathrm{C}$ for 48 hours. 
At the end of the incubation time, an evaluation of the growth and detection of the hydrolysis halos was carried out. The proteolytic and lipolytic activity was determined by the formation of a light halo around the colony and the amylolytic by the formation of a light yellow halo after adding the Lugol reagent [18]. The microorganisms that presented any of the three hydrolytic activities [18] were characterized macroscopically and microscopically from their growth in Nutrient agar at $35^{\circ} \mathrm{C} \pm 0.5^{\circ} \mathrm{C}$ for 48 hours.

\subsubsection{Determination of tolerance to pharmaceutical compounds by morphotypes}

To determine tolerance to NSAID-type pharmaceutical compounds, such as acetaminophen, ibuprofen and diclofenac, the Replica Plating method was used, carrying out three successive passes [19] using solid minimal salt medium (MSM) [20] which was modified (MSM: $\mathrm{MgSO}_{4}$ $0.20 \mathrm{~g} / \mathrm{L}, \mathrm{CaCl}_{2} 0.02 \mathrm{~g} / \mathrm{L}, \mathrm{K}_{2} \mathrm{HPO}_{4} 1.0 \mathrm{~g} / \mathrm{L}, \mathrm{KH}_{2} \mathrm{PO}_{4}$ $1.0 \mathrm{~g} / \mathrm{L}, \mathrm{NH}_{4} \mathrm{Cl} 1.0 \mathrm{~g} / \mathrm{L}, \mathrm{FeCl}_{3} 0.05 \mathrm{~g} / \mathrm{L}$, Base agar $18 \mathrm{~g} / \mathrm{L}$ ), after the sterilization process, the MSM was supplemented with a single carbon source of Glaxo SmithKline brand acetaminophen (50 mg/L), Genfar brand ibuprofen $(50 \mathrm{mg} / \mathrm{L})$ or Genfar brand diclofenac $(50 \mathrm{mg} / \mathrm{L})$.

The boxes were incubated at $35^{\circ} \mathrm{C} \pm 0.5^{\circ} \mathrm{C}$ for 48 hours. This process was repeated three consecutive times to guarantee the depletion of nutritional reserves. Tolerance to pharmaceutical compounds was determined by the presence/absence of growth after three consecutive passages in MSM supplemented with the drug as the sole carbon source.

From the NSAID-tolerant strains, an approximation was made to the minimum inhibitory concentration (MIC) for each of the contaminants. The Replica Plating method [19] was carried out, increasing the concentrations for each of the NSAIDs until reaching the maximum over-thecounter concentration in the pharmacy for acetaminophen (100 mg/L, $200 \mathrm{mg} / \mathrm{L}, 300 \mathrm{mg} / \mathrm{L}, 400 \mathrm{mg} / \mathrm{L}, 500 \mathrm{mg} / \mathrm{L})$, ibuprofen $(100 \mathrm{mg} / \mathrm{L}, 200 \mathrm{mg} / \mathrm{L}, 300 \mathrm{mg} / \mathrm{L}, 400 \mathrm{mg} / \mathrm{L}$, $500 \mathrm{mg} / \mathrm{L}, 600 \mathrm{mg} / \mathrm{L}, 700 \mathrm{mg} / \mathrm{L}, 800 \mathrm{mg} / \mathrm{L}$ ), and diclofenac (75 mg/L, $100 \mathrm{mg} / \mathrm{L})$. The morphotypes were incubated at $35^{\circ} \mathrm{C} \pm 0.5^{\circ} \mathrm{C}$ for $48 \mathrm{~h}$. After the incubation time, the presence or absence of growth was determined. The above allowed to determine which concentration of NSAIDs is tolerated by the selected morphotypes and in this way to be profiled for a mixed culture that removes organic matter in the nDWW of the pharmaceutical industry.

\subsection{Organic matter removal tests in nDWW of the pharmaceutical industry}

\subsubsection{Residual water}

From the wastewater treatment system of a pharmaceutical industry located in Bogota (Colombia), manufacturer of personal care products and NSAIDs, a specific sample was collected in June 2018, at which time the pharmaceutical industry was in the production of NSAIDs. The sampling point corresponded to the equalizer tank that allows controlling the flow of the influent and is subsequently passed to the secondary treatment processes arranged in the plant. Three samples were taken in amber flask, with a volume of one liter, purged three times before taking the sample. The sample was transported at $4{ }^{\circ} \mathrm{C}$ to the laboratory, and taken to the refrigerator, to be characterized in the following 24 hours [21].

\subsubsection{Physicochemical analysis}

Among the parameters that were analyzed for the water sample, acidity was performed by method 2310.A [22] and alkalinity by method 2320.B [22]. The parameters of hardness, dissolved oxygen, biological oxygen demand (BOD5), and chemical oxygen demand (COD) were carried out following the recommendations of the Institute of Hydrology, Meteorology and Environmental Studies [21]. For the pH measurement, a Hanna model HI-991301 pH meter [23] was used. These parameters were select because this is the minimum requirement evaluation for environmental authority in Colombia for wastewater in the pharmaceutical industry.

\subsubsection{Trial setup}

The morphotypes that showed growth in the MSM supplemented with the highest concentration of NSAIDs available in the pharmacy, were selected for the organic matter removal tests in nDWW of the pharmaceutical industry. Each morphotype was seeded in Erlenmeyer flask $250 \mathrm{~mL}$ holding $50 \mathrm{~mL}$ nutrient broth (Hi Media Laboratories, Pennsylvania, USA), and incubated at $35^{\circ} \mathrm{C} \pm 0.5^{\circ} \mathrm{C}$ for 18 hours in a shaker (Unimax 1010; Hieidolph, Germany) at $125 \mathrm{rpm}$.

The organic matter removal tests were carried out in triplicate for each of the morphotypes; in Erlenmeyer flask $500 \mathrm{~mL}$ holding $150 \mathrm{~mL}$ volume of wastewater taken from the pharmaceutical industry. The microbial inoculum 
constituted $10 \%$ of the effective working volume of the assemblies, with a concentration $106 \mathrm{cell} / \mathrm{mL}$. The removal of organic matter was determined based on the COD analysis, following the IDEAM protocols [21], the readings were made at times 0,24 and $48 \mathrm{~h}$.

Subsequently, the microorganisms that individually carried out the removal of organic matter in the $\mathrm{nDWW}$ greater than $50 \%$, were selected to be evaluated as a mixed culture. The assembly of the tests was carried out following similar conditions to those described for the individual morphotype tests. The inoculum was composed of the addition in equal proportion of each morphotype seeded in nutrient broth. Prior to reading, centrifugation (Hermle LaborTechnik, Z306, Germany) was performed at $5000 \mathrm{rpm}$ for 15 minutes to remove the biomass present in each of the samples.

\section{Results and analysis}

\subsection{Physicochemical analysis}

The wastewater sample was taking in the equalization tank, showed an average value $\mathrm{pH}$ of $\mathrm{pH} 7.89 \pm 0.02$ units as shown in Table 1, a value that is within the ranges established in Resolution 631 of 2015 of the Colombian Ministry of Environment and Sustainable Development for discharges [24]. This allows water to be classified as slightly alkaline and may be due to the type of substances used for the preparation of non-steroidal analgesics [25]. On the other hand, regarding the $\mathrm{BOD}_{5}$ parameter, an average of $648.33 \pm 2.88 \mathrm{mgO}_{2} / \mathrm{L}$ was found (Table 1), evidencing the presence of biodegradable organic matter and for the COD the value was $1522.33 \pm 2.51 \mathrm{mg} \mathrm{O} / \mathrm{L}$ (Table 1) indicating that the $\mathrm{nDWW}$ of the equalizer contains non-biodegradable organic matter, attributable to the production of NSAIDs, which are complex carbon molecules difficult to assimilate by microorganisms [26, 27].

Regarding the hardness of the nDWW sample, this characteristic is given mostly by the presence of calcium $\left(131.02 \pm 0.55 \mathrm{mg} \mathrm{CaCO}_{3} / \mathrm{L}\right)$, as can be seen in Table 1, which corresponds to those cations belonging to the group of alkaline earth that are dissolved in water and is generally related to the total concentration of calcium and magnesium ions [28]. Regarding alkalinity and acidity, it can be inferred that water has bicarbonate as the predominant element, taking into account that alkalinity is $165.66 \pm 0.57 \mathrm{mg} \mathrm{CaCO}_{3} / \mathrm{L}[29]$, probably because the process of manufacture of non-steroidal pain relievers uses calcium salts to stabilize their $\mathrm{pH}$.

\subsection{Microorganisms}

The morphotypes selected for this study, as mentioned above (FA morphotypes were isolated in Nutrient agar; $\mathrm{AB}$ and, $\mathrm{MB}$ morphotype were isolated in Cetrimide agar; ML was isolated in Macconkey agar), have hydrolytic metabolic activities related to the production of amylases that allow the degradation of sugars [30] by 4 morphotypes (FA 44, FA 47, FA 51 and FA 58), proteases for the transformation of proteins [31] by 6 morphotypes (FA 71, FA 75, $\mathrm{AB}$ 17, $\mathrm{AB} 21, \mathrm{MB} 9$ and ML 7) and lipases for the degradation of lipids [32] for 6 morphotypes (FA 9, FA 16, FA 17, FA 19, FA 25, FA 49). The microscopic morphology of the 16 chosen morphotypes corresponds to gram negative bacilli. Regarding macroscopic morphology, $12 \%$ of the morphotypes have colonies with irregular borders, all are small, only $12 \%$ are high and $24 \%$ are opaque. Pharmaceutical products are manufacture in different presentations like solubilized, solid, or liquid options. All dependent on the market needed, for the above, the strains their enzymatic capacity is the first essential quality because the microorganism will be faced with different forms of analgesics and will have to break down other carbon elements before consuming the NSAIDs as an energy source.

\subsection{Determination of tolerance to pharmaceutical compounds by morphotypes}

The microbial hydrolytic activity turns out to be a strategy for the decomposition of NSAIDs regardless of how these will be transformed into simpler molecules. That could be consuming as carbon sources by microorganisms, which prevents them from going into pharmaceutical industrial wastewater as an Emerging Pollutant that impacts

Table 1 Results physicochemical parameters

\begin{tabular}{|c|c|c|c|c|c|c|c|}
\hline Sample & $\mathrm{pH}$ & $\mathrm{BOD}_{5}\left(\mathrm{mg} \mathrm{O}_{2} / \mathrm{L}\right)$ & $\mathrm{COD}\left(\mathrm{mg} \mathrm{O}_{2} / \mathrm{L}\right)$ & $\begin{array}{c}\text { Acidity } \\
\left(\mathrm{CaCO}_{3} \mathrm{mg} / \mathrm{L}\right)\end{array}$ & $\begin{array}{l}\text { Calcium Hardness } \\
\left(\mathrm{CaCO}_{3} \mathrm{mg} / \mathrm{L}\right)\end{array}$ & $\begin{array}{l}\text { Total hardness } \\
\left(\mathrm{CaCO}_{3} \mathrm{mg} / \mathrm{L}\right)\end{array}$ & $\begin{array}{l}\text { Total alkalinity } \\
\left(\mathrm{CaCO}_{3} \mathrm{mg} / \mathrm{L}\right)\end{array}$ \\
\hline R1 & 7.91 & 650 & 1520 & 286 & 131.43 & 97.41 & 166 \\
\hline $\mathrm{R} 2$ & 7.88 & 645 & 1525 & 290 & 130.39 & 96.89 & 165 \\
\hline R3 & 7.88 & 650 & 1522 & 288 & 131.23 & 97.11 & 166 \\
\hline average & 7.89 & 648.33 & 1522.33 & 288 & 131.02 & 97.14 & 165.67 \\
\hline SD & 0.02 & 2.89 & 2.52 & 2 & 0.55 & 0.26 & 0.58 \\
\hline
\end{tabular}


ecosystems. From the growth in MSM supplemented with $50 \mathrm{mg} / \mathrm{L}$ of the three NSAIDs (acetaminophen, ibuprofen, and diclofenac), the 16 morphotypes showed growth after four successive passages and began with increasing concentrations, as described in the methodology, until reaching the maximum concentration of over-the-counter pharmacy. As it can be seen in Table 2, the morphotypes with the ability to grow in the three NSAIDs: acetaminophen at $500 \mathrm{mg} / \mathrm{L}$, ibuprofen at $800 \mathrm{mg} / \mathrm{L}$, and diclofenac at $100 \mathrm{mg} / \mathrm{L}$, were FA 17, FA 25, FA 44, FA 49, FA 71, FA 75, AB 17, AB 21, MB 9 and ML 7.

The importance of detecting microorganisms with the ability to use NSAIDs as the sole carbon source lies in the fact that recent studies have shown the presence of different drugs in urban wastewater in Colombia (influent and effluent from the El Salitre treatment plant in Bogota), such as acetaminophen, carbamazepine, clarithromycin, diclofenac, ibuprofen, losartan, valsartan, among others [33]. The possibility of finding environmentally friendly alternatives, such as the use of indigenous microorganisms, opens up the possibility of improving wastewater treatment plants and reducing the input of Emerging Pollutants into ecosystems.

\subsection{Organic matter removal tests in nDWW of the pharmaceutical industry}

The COD tests were performed on each of the microorganisms that were able to grow at the maximum concentration of NSAIDs to establish the reduction of organic matter.
The tests were carried out in triplicate and readings were made at 0, 24 and 48 hours, as shown in Fig. 1. It is evidenced that the removal percentages at the end of 48 hours were between $45.61 \%$ (FA 44) and $89.80 \%$ (FA25) respectively. Considering that the final removal percentages were above $50 \%$, the morphotypes FA 49 (88.75\%), FA 25 (89.90\%), FA 71 (67.65\%), FA 75 (79.41\%), AB 21 (62.96\%), MB 9 (84.98\%), ML 7 (81.73\%) and AB 17 (67.70\%). Only FA 17 (49.67\%) and FA44 (45.61) didn't remove that $50 \%$ COD in 48 hours. This morphotype will probably need more time to be effective if they work individual remotion COD in a wastewater biological treatment.

These were used in mixed culture as free cells to perform COD assays from the selection of the morphotypes. The measure was at 24 and 48 hours. At 24 hours the mixed culture removes $55.42 \% \mathrm{COD}(677.67 \pm 2.52 \mathrm{mg} \mathrm{O} / \mathrm{L})$ and, in 48 hours the mixed culture removes $92.28 \%$ COD $\left(117.33 \pm 2.03 \mathrm{mg} \mathrm{O}_{2} / \mathrm{L}\right)$.

Taking into account the national legislation where reference is made that to carry out the discharging of the limit value for COD corresponds to $150 \mathrm{mgO}_{2} / \mathrm{L}$ [24], it can be mentioned that the mixed culture is effective in the removal of organic matter, evidencing in the 48 hours a removal of $90.59 \%$ and with an average of $117.67 \mathrm{mgO}_{2} / \mathrm{L}$ of COD. This allows microorganisms to be profiled as an alternative to be incorporated into the nDWW treatment system of the pharmaceutical industry and to comply with national legislation, together

Table 2 Ability of the morphotypes to grow in NSAIDs

\begin{tabular}{|c|c|c|c|c|c|c|c|c|c|c|c|c|c|c|c|c|c|c|}
\hline \multirow{2}{*}{$\begin{array}{l}\text { Morpho } \\
\text { type }\end{array}$} & \multicolumn{6}{|c|}{ Acetaminophen (mg/L) } & \multicolumn{9}{|c|}{ Ibuprofen (mg/L) } & \multicolumn{3}{|c|}{ Diclofenac $(\mathrm{mg} / \mathrm{L})$} \\
\hline & 50 & 100 & 200 & 300 & 400 & 500 & 50 & 100 & 200 & 300 & 400 & 500 & 600 & 700 & 800 & 50 & 75 & 100 \\
\hline FA 9 & $* \mathrm{P}$ & $\mathrm{P}$ & $\mathrm{P}$ & $\mathrm{P}$ & $\mathrm{P}$ & $\mathrm{P}$ & $\mathrm{P}$ & $\mathrm{P}$ & $\mathrm{P}$ & $\mathrm{P}$ & $\mathrm{P}$ & $\mathrm{P}$ & $\mathrm{P}$ & $\mathrm{P}$ & $* * A$ & $\mathrm{P}$ & A & A \\
\hline FA 16 & $\mathrm{P}$ & $\mathrm{P}$ & $\mathrm{P}$ & $\mathrm{P}$ & $\mathrm{P}$ & $\mathrm{P}$ & $\mathrm{P}$ & $\mathrm{P}$ & $\mathrm{P}$ & $\mathrm{P}$ & $\mathrm{P}$ & $\mathrm{P}$ & $\mathrm{P}$ & A & A & $\mathrm{P}$ & A & A \\
\hline FA 17 & $\mathrm{P}$ & $\mathrm{P}$ & $\mathrm{P}$ & $\mathrm{P}$ & $\mathrm{P}$ & $\mathrm{P}$ & $\mathrm{P}$ & $\mathrm{P}$ & $\mathrm{P}$ & $\mathrm{P}$ & $\mathrm{P}$ & $\mathrm{P}$ & $\mathrm{P}$ & $\mathrm{P}$ & A & $\mathrm{P}$ & A & A \\
\hline FA 19 & $\mathrm{P}$ & $\mathrm{P}$ & $\mathrm{P}$ & $\mathrm{P}$ & $\mathrm{P}$ & $\mathrm{P}$ & $\mathrm{P}$ & $\mathrm{P}$ & $\mathrm{P}$ & $\mathrm{P}$ & $\mathrm{P}$ & $\mathrm{P}$ & $\mathrm{P}$ & A & A & $\mathrm{P}$ & A & A \\
\hline FA 25 & $\mathrm{P}$ & $\mathrm{P}$ & $\mathrm{P}$ & $\mathrm{P}$ & $\mathrm{P}$ & $\mathrm{P}$ & $\mathrm{P}$ & $\mathrm{P}$ & $\mathrm{P}$ & $\mathrm{P}$ & $\mathrm{P}$ & $\mathrm{P}$ & $\mathrm{P}$ & $\mathrm{P}$ & $\mathrm{P}$ & $\mathrm{P}$ & $\mathrm{P}$ & $\mathrm{P}$ \\
\hline FA 44 & $\mathrm{P}$ & $\mathrm{P}$ & $\mathrm{P}$ & $\mathrm{P}$ & $\mathrm{P}$ & A & $\mathrm{P}$ & $\mathrm{P}$ & $\mathrm{P}$ & $\mathrm{P}$ & $\mathrm{P}$ & $\mathrm{P}$ & A & A & A & $\mathrm{P}$ & $\mathrm{P}$ & $\mathrm{P}$ \\
\hline FA 47 & $\mathrm{P}$ & $\mathrm{P}$ & $\mathrm{P}$ & $\mathrm{P}$ & $\mathrm{P}$ & A & $\mathrm{P}$ & $\mathrm{P}$ & $\mathrm{P}$ & $\mathrm{P}$ & $\mathrm{P}$ & $\mathrm{P}$ & A & A & A & $\mathrm{P}$ & A & A \\
\hline FA 49 & $\mathrm{P}$ & $\mathrm{P}$ & $\mathrm{P}$ & $\mathrm{P}$ & $\mathrm{P}$ & $\mathrm{P}$ & $\mathrm{P}$ & $\mathrm{P}$ & $\mathrm{P}$ & $\mathrm{P}$ & $\mathrm{P}$ & $\mathrm{P}$ & $\mathrm{P}$ & $\mathrm{P}$ & $\mathrm{P}$ & $\mathrm{P}$ & $\mathrm{P}$ & $\mathrm{P}$ \\
\hline FA 51 & $\mathrm{P}$ & $\mathrm{P}$ & $\mathrm{P}$ & $\mathrm{P}$ & $\mathrm{P}$ & A & $\mathrm{P}$ & $\mathrm{P}$ & $\mathrm{P}$ & $\mathrm{P}$ & $\mathrm{P}$ & A & A & A & A & $\mathrm{P}$ & A & A \\
\hline FA 58 & $\mathrm{P}$ & $\mathrm{P}$ & $\mathrm{P}$ & $\mathrm{P}$ & $\mathrm{P}$ & A & $\mathrm{P}$ & $\mathrm{P}$ & $\mathrm{P}$ & $\mathrm{P}$ & $\mathrm{P}$ & $\mathrm{P}$ & A & A & A & $\mathrm{P}$ & A & A \\
\hline FA 71 & $\mathrm{P}$ & $\mathrm{P}$ & $\mathrm{P}$ & $\mathrm{P}$ & $\mathrm{P}$ & $\mathrm{P}$ & $\mathrm{P}$ & $\mathrm{P}$ & $\mathrm{P}$ & $\mathrm{P}$ & $\mathrm{P}$ & $\mathrm{P}$ & $\mathrm{P}$ & $\mathrm{P}$ & $\mathrm{P}$ & $\mathrm{P}$ & $\mathrm{P}$ & $\mathrm{P}$ \\
\hline FA 75 & $\mathrm{P}$ & $\mathrm{P}$ & $\mathrm{P}$ & $\mathrm{P}$ & $\mathrm{P}$ & $\mathrm{P}$ & $\mathrm{P}$ & $\mathrm{P}$ & $\mathrm{P}$ & $\mathrm{P}$ & $\mathrm{P}$ & $\mathrm{P}$ & $\mathrm{P}$ & $\mathrm{P}$ & $\mathrm{P}$ & $\mathrm{P}$ & $\mathrm{P}$ & $\mathrm{P}$ \\
\hline AB 17 & $\mathrm{P}$ & $\mathrm{P}$ & $\mathrm{P}$ & $\mathrm{P}$ & $\mathrm{P}$ & $\mathrm{P}$ & $\mathrm{P}$ & $\mathrm{P}$ & $\mathrm{P}$ & $\mathrm{P}$ & $\mathrm{P}$ & $\mathrm{P}$ & $\mathrm{P}$ & $\mathrm{P}$ & $\mathrm{P}$ & $\mathrm{P}$ & $\mathrm{P}$ & $\mathrm{P}$ \\
\hline AB 21 & $\mathrm{P}$ & $\mathrm{P}$ & $\mathrm{P}$ & $\mathrm{P}$ & $\mathrm{P}$ & $\mathrm{P}$ & $\mathrm{P}$ & $\mathrm{P}$ & $\mathrm{P}$ & $\mathrm{P}$ & $\mathrm{P}$ & $\mathrm{P}$ & $\mathrm{P}$ & $\mathrm{P}$ & $\mathrm{P}$ & $\mathrm{P}$ & $\mathrm{P}$ & $\mathrm{P}$ \\
\hline MB 9 & $\mathrm{P}$ & $\mathrm{P}$ & $\mathrm{P}$ & $\mathrm{P}$ & $\mathrm{P}$ & $\mathrm{P}$ & $\mathrm{P}$ & $\mathrm{P}$ & $\mathrm{P}$ & $\mathrm{P}$ & $\mathrm{P}$ & $\mathrm{P}$ & $\mathrm{P}$ & $\mathrm{P}$ & $\mathrm{P}$ & $\mathrm{P}$ & $\mathrm{P}$ & $\mathrm{P}$ \\
\hline ML 7 & $\mathrm{P}$ & $\mathrm{P}$ & $\mathrm{P}$ & $\mathrm{P}$ & $\mathrm{P}$ & $\mathrm{P}$ & $\mathrm{P}$ & $\mathrm{P}$ & $\mathrm{P}$ & $\mathrm{P}$ & $\mathrm{P}$ & $\mathrm{P}$ & $\mathrm{P}$ & $\mathrm{P}$ & $\mathrm{P}$ & $\mathrm{P}$ & $\mathrm{P}$ & $\mathrm{P}$ \\
\hline
\end{tabular}




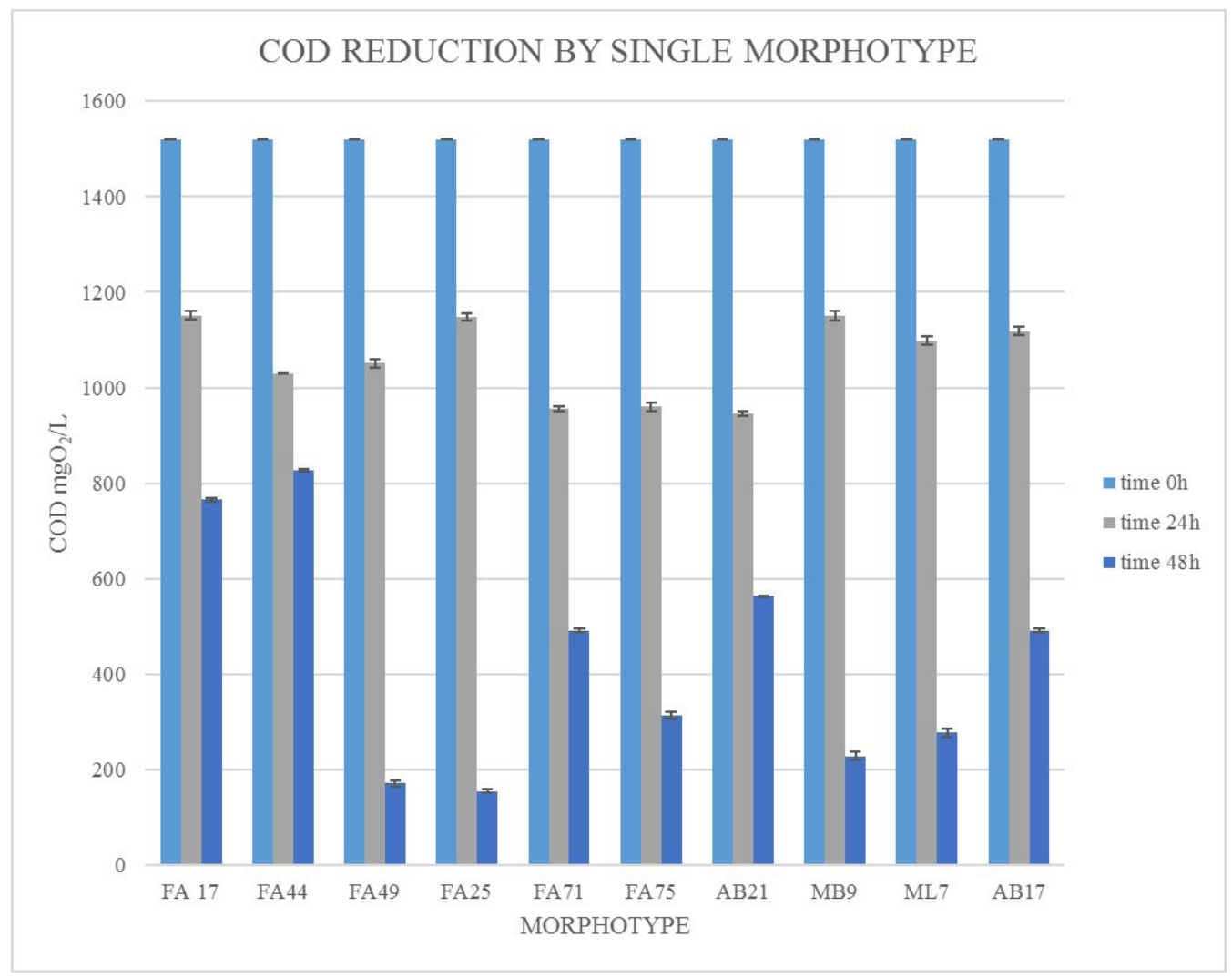

Fig. 1 COD measurement to establish the removal of organic matter by morphotypes

with the possibility of using NSAIDs that enter the system and prevent them from reaching surface waters [34]. Additionally, biological systems can be more effective in terms of removing organic matter in wastewater from the pharmaceutical industry when compared to studies where coagulation is used, and the removal of COD was only $49 \%[35,36]$. Other authors apply for treatment of pharmaceutical industry wastewater a combination into electrocoagulation, electro-Fenton, and photocatalytic oxidation, where the effective remotion was observed $64 \%$ total organic carbon and $70.2 \%$ COD [37]; for remotion of $99 \% \mathrm{COD}$ in wastewater pharmaceutical industry combination between micro-electrolysis and Fenton oxidation-coagulation, this study needed 90 days to almost remove COD wholly [38]. In the future, a possible combination of physicochemical technologies with a biological treatment could reduce the time of COD remotion and additionally remove Emerging Pollutants in wastewater.

\section{Conclusions}

Treatment systems for Non-Domestic Wastewater focus on the efficiency of the removal of organic matter, however, Emerging Pollutants such as personal care products and medicines are not considered within the system, since national legislation still does not have them contemplated in the surveillance and control procedures.

Performing bioprospecting processes of microorganisms with enzymatic abilities allows the selection of strains with the ability to mineralize Emerging Pollutants such as acetaminophen, ibuprofen, and diclofenac to improve the current $\mathrm{nDWW}$ treatment systems available to the pharmaceutical industry. In this way, the efficiency in the removal of organic matter and compliance with the parameters required by current legislation is maintained, added to the mineralization of other substances that are being detected in water sources, and that every day increases the concern in the scientific community.

The ability to tolerate pharmaceutical compounds allows establishing a consortium that is not inhibited by the presence of complex organic compounds and that in the future can be implemented as a strategy for their removal.

\section{Acknowledgments}

Product derived from the IMP-ING-2655 project financed by the Vice-Rector's Office for Research of the Universidad Militar Nueva Granada - Validity 2019. The authors are grateful for the contributions made by the M.Cs. Silvia Narváez Florez. 


\section{References}

[1] Anbarasu, K., Anbuselvan G. "Physico-chemical parameter analysis of water in Musiri Taluk, Tamil Nadu, India", World News of Natural Sciences, 6, pp. 36-43, 2017. [online] Available at: http:// www.worldnewsnaturalsciences.com/wp-content/uploads/2012/11/ WNOFNS-6-2017-36-43-3.pdf [Accessed: 20 November 2020]

[2] de Oliveira, D. B., de Oliveira Junior, H. M., Sales, P.D.T. F., Schimidt, F., Santiago, M. F., Campos, L. C. "Characterization and genotoxicity evaluation of effluent from a pharmacy industry", Revista Ambiente \& Água - An Interdisciplinary Journal of Applied Science, 8(2), pp. 34-45, 2013.

https://doi.org/10.4136/ambi-agua.1107

[3] Mercado Martínez, I. D., González Silva, G., Valencia Hurtado, S. H. "Remoción de níquel y dqo presentes en las aguas residuales de la industria automotriz mediante electrocoagulación" (Removal of Nickel and COD present in automotive wastewater by electrocoagulation), Revista EIA Escuela Ingeniería Antioquia, 10(19), pp. 13-21, 2013. [online] Available at: http://www.scielo.org.co/pdf/eia/n19/n19a02. pdf [Accessed: 20 November 2020] (in Spanish)

[4] Sabliy, L., Kuzminskiy, Y., Zhukova, V., Kozar, M., Sobczuk, H. "New Approaches in Biological Wastewater Treatment Aimed at Removal of Organic Matter and Nutrients", Ecological Chemistry and Engineering S, 26(2), pp. 331-343, 2019.

https://doi.org/10.1515/eces-2019-0023

[5] Altenburger, R., Ait-Aissa, S., Antczak, P., Backhaus, T., Barceló, D., Seiler, T. B., ..., Brack, W. "Future water quality monitoring - Adapting tools to deal with mixtures of pollutants in water resource management", Science of The Total Environment, 512-513, pp. 540-551, 2015.

https://doi.org/10.1016/j.scitotenv.2014.12.057

[6] Schymanski, E. L., Singer, H. P., Slobodnik, J., Ipolyi, I. M., Oswald, P., Krauss,..., Hollender, J. "Non-target screening with high-resolution mass spectrometry: critical review using a collaborative trial on water analysis", Analytical and Bioanalytical Chemistry, 407(21), pp. 6237-6255, 2015. https://doi.org/10.1007/s00216-015-8681-7

[7] Hernández-Domínguez, C., Álvarez-Muñoz, P., Zapa-Cedeño, J. "Técnicas analíticas para el control de la contaminaciónn Ambiental" (Analytical techniques for environmental pollution control), Revista Ciencia UNEMI, 9(20), pp. 118-131, 2016. (in Spanish) https://doi.org/10.29076/issn.2528-7737vo19iss20.2016pp118-131p

[8] Santamaría, E., Álvarez, F., Santamaría, E., Zamora, M. "Caracterización de los parámetros de calidad del agua para disminuir la contaminación durante el procesamiento de lácteos" (Characterization of water quality parameters to reduce contamination during dairy processing), Agroindustrial Science, 5(1), pp. 13-26, 2015. (in Spanish) https://doi.org/10.17268/agroind.science.2015.01.02

[9] García-Gómez, C., Gortáres-Moroyoqui, P., Drogui, P. "Contaminantes emergentes: efectos y tratamientos de remoción" (Emerging contaminants: effects and removal treatments), Revista QuímicaViva, 10(2), pp. 96-105, 2011. [online] Available at: https://www.redalyc.org/articulo.oa?id=86319141004 [Accessed: 02 February 2021] (in Spanish)
[10] Petrie, B., Barden, R., Kasprzyk-Hordern, B. "A review on emerging contaminants in wastewaters and the environment: Current knowledge, understudied areas and recommendations for futures monitoring", Water Research 72, pp. 3-27, 2015.

https://doi.org/10.1016/j.watres.2014.08.053

[11] Wang, J., Wang, S. "Removal of pharmaceuticals and personal care products (PPCPs) from wastewater: A review", Journal of Environmental Management, 182, pp. 620-640, 2016. https://doi.org/10.1016/j.jenvman.2016.07.049

[12] Gil, M. J, Soto, A. M., Usma, J. I., Gutiérrez, O. D. "Contaminantes emergentes en aguas, efectos y posibles tratamientos" (Emerging contaminants in water, effects and possible treatments), Producción + Limpia, 7(2), pp. 52-73, 2012. [online] Available at: http://www.scielo.org.co/scielo.php?script=sci_arttext\&pid=S190904552012000200005\&lng=en\&nrm=iso > [Accessed: 02 February 2021] (in Spanish)

[13] Tejada, C., Quiñonez, E., Peña, M. "Contaminantes Emergentes en Aguas: Metabolitos de Fármacos. Una Revisión" (Emerging Contaminants in Waters: Drug Metabolites), Revista Facultad de Ciencias Básicas, 10(1), pp. 80-101, 2014. (in Spanish) https://doi.org/10.18359/rfcb.341

[14] Fang, T-H., Nan, F-H., Chin, T-S., Feng, H-M. "The occurrence and distribution of pharmaceutical compounds in the effluents of major sewage treatment plant in Northern Taiwan and the receiving coastal waters", Marine Pollution Bulletin, 64(7), pp. 1435-1444, 2012. https://doi.org/10.1016/j.marpolbul.2012.04.008

[15] Alvarino, T., Suarez, S., Lema, J., Omil, F. "Understanding the sorption and biotransformation of organic micropollutants in innovative biological wastewater treatment technologies", Science of The Total Environment, 615, pp. 297-306, 2018. https://doi.org/10.1016/j.scitotenv.2017.09.278

[16] Ahmed, M. B., Zhou, J. L., Ngo, H. H., Guo, W., Thomaidis, N. S., $\mathrm{Xu}, \mathrm{J}$. "Progress in the biological and chemical treatment technologies for emerging contaminant removal from wastewater: A critical review", Journal of Hazardous Materials, 323(Part A), pp. 274-298, 2017. https://doi.org/10.1016/j.jhazmat.2016.04.045

[17] de Pascale, D., De Santi, C., Fu, J., Landfald, B. "The microbial diversity of Polar environments is a fertile ground for bioprospecting", Marine Genomics, 8, pp. 15-22, 2012. https://doi.org/10.1016/j.margen.2012.04.004

[18] Mondal, S., Roy, T., Ray, A. K. "Characterization and Identification of Enzyme-producing Bacteria Isolated form the Digestive Tract of Bata, Labeo bata", Journal of the World Aquaculture Society, 41(3), pp. 369-377, 2010. https://doi.org/10.1111/j.1749-7345.2010.00378.x

[19] Lederberg, J., Lederberg, E. M. "Replica plating and indirect selection of bacterial mutants", Journal of Bacteriology, 63(3), pp. 399-406, 1952. https://doi.org/10.1128/jb.63.3.399-406.1952

[20] Bushnell, L. D., Haas, H. F. "The Utilization of Certain Hydrocarbons by Microorganisms", Journal of Bacteriology, 41(5), pp. 653-673, 1941. https://doi.org/10.1128/jb.41.5.653-673.1941 
[21] Rodríguez, C. H. "Demanda Quìmica de Oxìgeno por Reflujo Cerrado y Volumetria" (Chemical Oxygen Demand by Closed Reflux and Volumetry), Instituto de Hidrología, Meteorología y Estudios Ambientales - IDEAM, Bogota, D.C., Colombia, Rep. TP0086, Version: 05, 2007. [online] Available at: http://www.ideam.gov.co/documents/14691/38155/ Demanda+Qu\%C3\%ADmica+de+Ox\%C3\%ADgeno. pdf/20030922-4f81-4e8f-841c-c124b9ab5adb [Accessed: 17 May 2020] (in Spanish)

[22] Laura Bridgewater, American Public Health Association (APHA), American Water Works Association, Water Environment Federation "Standard method for the examination of water and wastewater", American Public Health Association, Washington, DC, USA, 2012.

[23] José Benito Vives de Andréis Marine and Coastal Research Institute "Manual de técnicasanalíticas para la determinaciónde parámetros fisicoquímicosy contaminantes marinos (aguas, sedimentos y organismos)" (Manual of Analytical Techniques for the Determination of Physicochemical Parameters and Marine Pollutants (Water, Sediments and Organisms)), [pdf] INVEMAR, Santa Marta, Colombia, 2003. Available at: http://www.invemar. org.co/redcostera1/invemar/docs/7010manualTecnicasanaliticas. pdf [Accessed: 17 May 2020] (in Spanish)

[24] Ministerio de Ambiente y Desarrollo Sostenible "Resolucion 0631 por la cual se establecen los parametros y los valores límites máximos permisibles en los vertimientos puntuales a cuerpos de aguas superficiales y a los sistemas de alcantarillado público y se dictan otras dispociniones" (Resolution 0631 whereby the parameters and maximum permissible limit values for point discharges into surface water bodies and public sewage systems are established and other provisions are issued), [pdf] Ministerio de Ambiente y Desarollo Sostenible, Bogota, Columbia, 2015. Available at: https://www.minambiente.gov.co/ images/normativa/app/resoluciones/d1-res_631_marz_2015.pdf [Accessed: 17 May 2020] (in Spanish)

[25] Saxena, N., Sharma, A. "Evaluation of Water Quality Index for Drinking Purpose in and Around Tekanpur area, M.P. India", International Journal of Applied Environmental Sciences, 12(2), pp. 359-370, 2017. [online] Available at: https://www.ripublication. com/ijaes17/ijaesv12n2_14.pdf [Accessed: 20 February 2021]

[26] Castillo Borges, E. R., Bolio Rojas, A., Méndez Novelo, R. I., Osorio Rodríguez, J. H., Pat Canul, R. "Remoción de materia orgánica en aguas residuales de rastro por el proceso de Contactor Biológico Rotacional" (Removal of organic matter in trace wastewater by the Rotational Biological Contactor process), Ingeniería, 16(2), pp. 83-91, 2012. [online] Available at: https:// www.redalyc.org/articulo.oa?id=46725067001 [Accessed: 20 January 2021] (in Spanish)

[27] Evgenidou, E. N., Konstantinou, I. K., Lambropoulou, D. A. "Occurrence and removal of transformation products of PPCPs and illicit drugs in wastewaters: A review", Science of The Total Environment, 505, pp. 905-926, 2015. https://doi.org/10.1016/j.scitotenv.2014.10.021
[28] Capote, T. J., Matute, S. B., Rojas, J. R. "Determinación de la dureza total en agua con EDTA empleando una solución amortiguadora inodora de borato", (Total hardness water determination by EDTA using a olorless buffer borate), Revista del Instituto Nacional de Higiene "Rafael Rangel", 46(1-2), pp. 17-24. 2015. [online] Available at: http://ve.scielo.org/scielo. php?script=sci_arttext\&pid=S0798-04772015000100003\&lng=es \&nrm=iso [Accessed: 20 January 2021] (in Spanish)

[29] Pérez-López, E. "Control de calidad en aguas para consumo humano en la región occidental de Costa Rica" (Quality control in water for human consumption in the western region of Costa Rica), Revista Tecnología en Marcha, 29(3), pp. 3-14, 2016. (in Spanish) https://doi.org/10.18845/tm.v29i3.2884

[30] Moreno, M. Q., Montoya Campuzano, O. I., Gutiérrez Sanchez, P. A. "Purificación y Caracterización de Una $\alpha$-Amilasa Producida Por La Cepa Nativa Bacillus Sp. BBM1" (Purification and characterization of a $\alpha$-amylase produced by the native strain Bacillus sp. BBM1), Dyna, 162(1), pp. 31-38, 2009. [online] Available at: https://pascal-francis.inist.fr/vibad/index. php?action=getRecordDetail\&idt=23239838 [Accessed: 02 February 2021] (in Spanish)

[31] Hernández-Sámano, A. C., Guzmán-García, X., García-Barrientos, R., Ascencio-Valle F., Sierra-Beltrán, A., Vallejo-Córdoba, B., GonzalezCórdova,A. F., Torres-Llanez, M. J., Guerrero-Legarreta, I. "Extracción y caracterización de proteasas de pepino de mar Isostichopus fuscus recolectado en el Golfo de California, México" (Extraction and characterization of sea cucumber Isostichopus fuscus proteases, collected in the Gulf of California, Mexico), Revista Mexicana de Ingeniería Química, 14(1), pp. 35-47, 2015. [online] Available at: http://www.scielo.org.mx/scielo.php?script=sci_arttext\&pid=S166527382015000100004\&lng=es\&nrm=iso [Accessed: 20 February 2021] (in Spanish)

[32] González-Bacerio, J., Rodríguez Hernández, J., del Monte Martínez, A. "Las lipasas: enzimas con potencial para el desarrollo de biocatalizadores inmovilizados por adsorción interfacial" (Lipases: enzymes with potential for the development of biocatalysts immobilized by interfacial adsorption), Revista Colombiana de Biotecnología, 12(1), pp. 124-140, 2010. [online] Available at: https://revistas.unal.edu.co/index.php/biotecnologia/article/ view/15574/38075 [Accessed: 02 February 2021] (in Spanish)

[33] Hernández, F., Ibáñez, M., Botero-Coy, A-M., Bade, R., BustosLópez, M. C., Rincón, J., Moncayo, A., Bijlsma, L. "LC-QTOF MS screening of more than 1,000 licit and illicit drugs and their metabolites in wastewater and surface waters from the area of Bogotá, Colombia", Analytical and Bioanalytical Chemistry, 407(21), pp. 6405-6416, 2015. https://doi.org/10.1007/s00216-015-8796-x

[34] Quiroga Alonso, J. M., Quero-Pastor, M. J., Acevedo Merino, A. "Tratamientos avanzados para la eliminación de fármacos en aguas superficiales" (Advanced treatments for the elimination of drugs in surface waters), Revista de Salud Ambiental, 15, pp. 12-64, 2015. [online] Available at: https://ojs.diffundit.com/index.php/rsa/ article/view/733 [Accessed: 02 February 2021] (in Spanish) 
[35] Goodarzi, Sh., Khoramabadi, G. S., Esmaty, M., Karami, M. A., Panahi, A. H. "Investigating the efficiency of chemical coagulation/Elctro-Fenton process in the removal of organic matter from pharmaceutical industry wastewater", Iranian Journal of Health and Environment, 12(2), pp. 257-272, 2019. [online] Available at: https://ijhe.tums.ac.ir/article-1-6215-en. html [Accessed: 15 January 2021]

[36] Quian, F., He, M., Wu, J., Yu, H., Duan, L. "Insight into removal of dissolved organic matter in post pharmaceutical wastewater by coagulation-UV/H2O2", Journal of Environmental Sciences, 76, pp. 329-338, 2019

https://doi.org/10.1016/j.jes.2018.05.025
[37] Dindas, G. B., Çalışkan, Y., Çelebi, E. E., Tekbaş, M., Bektaş, N., Yatmaz, H. C. "Treatment of pharmaceutical wastewater by combination of electrocoagulation, electro-fenton and photocatalytic oxidation processes", Journal of Environmental Chemical Engineering, 8(3), Article number: 103777, 2020. https://doi.org/10.1016/j.jece.2020.103777

[38] Xu, X., Cheng, Y., Zhang, T., Ji, F., Xu, X. "Treatment of pharmaceutical wastewater using interior micro-electrolysis/Fenton oxidation-coagulation and biological degradation", Chemosphere, 152, pp. 23-30, 2016.

https://doi.org/10.1016/j.chemosphere.2016.02.100 